\title{
SEMIOTIC ANALYSIS AND PERSUASIVE DISCOURSE TO THE BILLBOARD OF LEGISLATIVE CANDIDATES 2019 IN INDONESIA
}

\author{
Lely Rahmawati ${ }^{1}$ \\ Universitas Negeri Jakarta \\ Emzir $^{2}$ \\ Universitas Negeri Jakarta \\ Shafruddin Tajuddin ${ }^{3}$ \\ Universitas Negeri Jakarta
}

lelyrahmawati_lt17s2@mahasiswa.iunj.ac.id ${ }^{1}$

Submit, 16-04-2020 Accepted, 13-06-2020 Publish, 14-06-2020

\begin{abstract}
This study aims to scrutinize the utilization both of visual and written language toward the billboard of legislative candidates in the general election 2019. The sources of the data are 2 billboards from 9 parties winning the general election 2019 in Indonesia and the data that has been taken by the researchers are slogans and photos which have been deployed on the billboards. This qualitative research uses the method of descriptive analysis. On billboard 1 (Golkar), the dominance of the persuasive discourse is a wise clause which has been deployed to build a good reputation about legislative candidates. Meanwhile on billboard 2 (PKS), the dominance is the invitation which indicated that the legislative candidates directly invited the people to choose them. Through the visual and written language, the legislative candidates showed their identities strongly. Briefly, these billboards which showed in this research contained the strong persuasive language which combined both of written and visual languages.
\end{abstract}

Keywords: Language, Persuasive, Visual, Parties

\section{INTRODUCTION}

The political situation in Indonesia especially in 2019 has gotten alluring to be explored since it was the first time for Indonesia to hold general elections for president, house of representative, regional house of representative and regional representative board only in one day. Indonesia has been holding general elections for 12 times since 1955 in which became the first general election during Soekarno's era. The general election that is held once in every five years have brought the competitive atmosphere among the candidates, especially general 
election held on $17^{\text {th }}$ April 2019 in Indonesia. The campaign period started from 23th September 2018 until 13 ${ }^{\text {th }}$ April 2019. During the period of time, the candidates had tried many ways to get the voters as many as possible.

Based on the data that has obtained from www.worldometers.com in 2019, Indonesia is ranked fourth as the most populous country in the world with the number of populations as many as $269,589,785$ people. Meanwhile the official website of General Elections Commission in 2019 has posted that 192.8 million of Indonesian people have registered as the voters and the total number of candidates that involved in the general election are 245.000 candidates. There were 16 political parties which participated in general election 2019 in Indonesia. They are 1. National Awakening Party (PKB), 2. Great Indonesia Movement Party (GERINDRA), 3. Indonesian Democratic Party of Struggle (PDI PERJUANGAN), 4. Functional Group (GOLKAR), 5. NASDEM, 6. GARUDA, 7. BERKARYA, 8. Prosperous Justice Party (PKS), 9. PERINDO, 10. United Development Party (PPP), 11. PSI, 12. National Mandate Party (PAN), 13. People's Conscience Party (HANURA), 14. DEMOKRAT, 15. Crescent Star Party (PBB) 16. PKPI

Language is an effective tool for communication to convey our intention towards other people and it has involved the meaning to reach the communication in proper ways. Visual and written texts have become the factors which form a meaning in communication. This analysis will scrutinize the meaning deployed on the billboard through the visual and written text (tagline). And it will examine the political branding on the billboard which indirectly penetrate the awareness for those commuters who see the billboard. The purpose of this research is to disassemble the meaning on the billboard from the two winning parties in 2019 general election both of visual and written texts. The writers use two approaches to examine the research: first, social semiotics to analyze the visual language and second, persuasive discourse to understand the written texts such as taglines.

Billboard is a one of the tools which are used during the campaign to promote the candidates. There were many billboards of the candidates which were displayed along the public roads and lasted almost for six months since the period of campaign. And it has become the visual consumption for those who commute whether intentionally or unintentionally seeing the billboards. From those billboards, it could be seen that the candidates who advertised themselves got the sympathy from the public, and as the result, it could give the increasing number of voters in the general election.

The observation and research about the general elections in Indonesia conducted before the general election in 2019. Bahri, (2018) was conducted the research A Semiotic on the Headlines of Political Party's Advertisement in the 
Jakarta Post. The study intended at representing the rhetorical pattern from political party's advertisement at the time of the gubernatorial election in 2017.

Adhani et al., (n.d.) also examined the billboards as the media which was used in the North Sumatra gubernatorial election campaign in 2018. The author analyzes the prospective governor and vice governor candidates in embracing various tribes who live in North Sumatra province through the approach of political communication and local culture. The researcher has found that the Billboards are not only used as a venue for self-introduction but also used by the candidates in the North Sumatra governor election in 2018 to gain the sympathy of the voters through their the cultural approaches. This study uses a quantitative method when the researcher distributes the questionnaires into the 70 respondents to assess their satisfaction with the message conveyed through billboards. The results of the survey had showed that there were 36 correspondents who rated the billboard to be trusted, 29 people said that the billboards were very good to be trusted, and 5 people stated that billboards were not good to be trusted.

Khan et al., (2016) has analyze the characteristic of rethoric discourse General Election in Pakistan. Based on the results, it can be identified that there are the techniques on the rhetorical such as ethos which deals with characters, pathos refers to feelings of mercy and logos includes content. These three techniques on the rhetoric are manifested in billboards and uses to interpret the messages on the advertisement. Both of these journal did not examined about the perspective from social semiotic.

Sulastri \& Ronidin, (2016) this study explores the language billboards which present in a range of linguistic symbols that contain the credible message from the candidates and the parties. The writer uses a semiotic approach to find out the meaning both in language and nonlinguistic aspects. The results show the existences of persuasive on billboards are manifested through symbols with signified the characteristics of the choice of languages.

Rizki et al., (2019) analyze definitely on the use of political symbols and images in Aceh. The writers achieve that the observed more attracted toward the charismatic candidates rather than many agendas which has been held by the parties. There are the difference between the research from Sulastri and Rizki between this journal, namely their journal did not scrutinize the linguistic aspects deeply.

Udalla, (2016) examines the capacities the presidential candidates' billboards show the significant character blur campaign in Nigeria, expanding the evaluation of language and social semiotic. The results reveals that the billboards not only produce the discursive about Islam strands, but also reverse delicating messages vilifying the other candidates. 
Everbach et al., (2019), their research focus on semiotic and discourse analysis of United States presidential campaign. This study utilizes semiotic analysis to verify the sign language in United States and comparing presidential campaign billboards. The semiotic analysis has found that the billboards presented Barrack Obama as a figure of familiar, and through the discourse analysis approach also propose that the billboards created John Kennedy an eventual patriot with a great leadership. Based on the two journals above, there are not analysis in linguistic aspect specifically.

If we are take a look on previous journals, none of them which scrutinized both of visual and written languages strongly. Based on these reason, the writers uses two approaches to analyzes written and visual languages separately, in order to get an accurate information about the dominances written and visual languages in the billboards.

\section{LITERATURE REVIEW}

Departing from the issues and phenomena in Indonesian politics specifically in general elections, the author is interested in examining issues in the general election through the billboards of candidates by using visual and written language analysis. It is because the research on general election issues in the billboards in 2019 rarely becomes the latest and hottest issue. In this study the authors used two approaches, namely analyzing visual language in the form of symbols and also photographs of the candidates by using social semiotics and persuasive discourse to analyze written language on the tagline printed on billboards.

Social semiotics is a theory which has been developed by (Leeuwen, 2018). According to Leeweun, (2018), semiotics is generally described as the study of signs. In every sign that appears, there always will be a meaning or sign that manifested through the form of expression or representation. Social semiotics is a branch of semiotics. In the community or association, there is a different sign that has become an agreement, for an example, based on the agreement which Chinese community has applied, the death is usually symbolized in white, even all devices and clothing during the funeral are dominated by white. Starting from candles, door curtains, lanterns, and clothes which worn by mourners. Meanwhile, black is identified with the color of mourning or the color of death universally (Leeuwen, 2018) has divided three types of metafunction in semiotics, namely: Representational metafunction, interpersonal metafunction and compositional metafunction. Representational metafunction is related to the participants which contained in the picture, participant attributes and all conditions and identification processes in the picture. 
In the representational metafunction, there is a narrative process that is like a story. A picture can create a story for those who see it. In the narrative process there are thoughts, words, actions and reactions of people who see the picture. While the conceptual process includes all the participants who are shown in the picture. We need to unite all the participants to find out the meaning on the picture.

Interpersonal metafunction has a correlation between the participants in the picture and the commuters. In this context there are several aspects involved, namely: eye sight, for example, the participants in images who present their faces and eyes directly towards the audience's perception, will create a close relationship. Likewise with social intimacy that will be created through the form of participants in the picture. If the participant is only raised by picture of the face, it can be engaged and involved the strong social intimacy between the participants and the commuters. But if the participants have displayed the whole body (head to toe), we can see that they are making a distance and do not want to 'talk' to us closely. The angle position of the image also affects the viewing angle of the eye of the beholder. For example: the angle in a horizontal position means that the participants become the part of us as the people who see it. Because it is able to create equality. Whereas in the vertical position, high and low positions indicate less power.

Compositional metafunctions are used to integrate between the representational and interpersonal metafunctions, as the result it can produce a meaning as a whole. There are basic systems and elements that exist in compositional metafunctions, namely: salience (important and prominent things), information value and framing. When we see an image, there will be an object that stands out and attracts our eyes, whether it is in the form of color domination, image size, etc. The position of the participants in the picture also has a meaning. For example: when there are two participants with the positions both on the right and on the left sides. The right-hand position means 'new', which is an issue, solution or problem. The left position indicates 'given' which is a figures who is familiar. Whereas framing looks at how participants are analysed either separately or as a whole.

Regarding persuasive discourse specifically in the political field, Spenkuch \& Toniatti, (2015) has explained that persuasion is defined as inviting someone through giving reasons that are so convincing, subtle persuasion with the aim of proving an opinion. Violence and coercion are not done in persuasion. Therefore, in the discourse of persuasion, we need a variety of ways that have been well designed to be able to stimulate someone in making decisions in accordance with the wishes that have been expressed by the author. Various efforts can be manifested through the provision of evidence, although not more assertive than in 
the discourse of argumentation. Richardson, (2007) has explained that from the perspective of the existing structure, the discourse of persuasion sometimes has the same structure as an argumentative texts. But in many cases, it depends on the situations and speakers.

Glavas, (2017) classifies several forms of persuasion in general, namely: (1) Advertising both in print and online media; (2) Propaganda that has been conducted by certain groups and (3) leaflets or pamphlets. Controlling one's mindset is the goal of persuasion, therefore the ad makers will be able to persuade and make others accept and do something related to the ad makers. In this context, legislative candidates try to build their self-image and the trust of the public to support a lot of votes.

\section{RESEARCH METHOD}

The qualitative approach is used by researchers in giving detailed exposures about the analysis both of visual and written language on the billboards of legislative candidates in the general election in 2019 , as the result, the researchers can uncover the use of language from the legislative candidates during campaign in general election 2019 in Indonesia.

In the analysis of both visual and written language, the researcher uses content analysis which aims to provide in-depth exposure to the social semiotic analysis and persuasive discourse which has been deployed on the billboard of legislative candidate during the general election 2019 in Indonesia. The place of research is conducted in the area of researcher's domicile, namely Jakarta and Bekasi (the cities located in Indonesia). This research is a qualitative research and carried out through descriptive analysis methods.

This study uses a stratified purposive sampling technique to analyze 2 billboards from 9 parties winning the general election 2019 in Indonesia. This sampling technique refers to the selection of samples in accordance with the research needs. The researchers use textual analysis to investigate both slogans and photos on the billboards by focusing on social semiotics and persuasive discourse. The researchers use textual analysis as a method that is used to interpret phenomena through one's interpretation of a text. By analyzing a text, the researcher can understand a person's perspective on the world and phenomena through the text that has been produced by the advertisers. In line with this research, the method of textual analysis used to analyze the language of euphemisms through texts written on billboards is supported by a framework of persuasive discourse analysis. Whereas to analyze the meaning of visual language on billboards, the writer uses social semiotics. 


\section{FINDINGS}

The research was carried out around the 2019 election campaign period, from January to April 2019. The data sources which are used in this study are photographs of legislative candidates, symbols and slogans that are displayed on the billboards of legislative candidate. While the data which are used in this analysis are two billboards in the two winning parties in the 2019 general election, namely the PDI-P which is a representative of the nationalist party and PKB as the Islamic party. The researchers have gathered the data by photographing directly in Jakarta and Bekasi.

The research conducted some procedures during the collection of the data, such as: (1) Photographing billboards of legislative candidates that has scattered in every corner of public space; (2) Classifying candidates' billboards based on political parties, both nationalist and Islam strands; (3) Classifying candidates' billboards based on the serial number.

The steps in analyzing data are divided into two types, that are: analysis for visuals (photo of candidates, symbols and colors) and writing analysis (slogans). In analyzing the visual languages, the researchers takes the following steps: (1) Gathering all the billboards; (2) Classifying based on parties of Nationalist and Islamic strands and based on the parties winning the Indonesia general election in 2019; (3) Analyzing the visual text of the legislative candidates' billboards based on three metafunctions language in social semiotics;

(4) Drawing the temporary conclusions.

Whereas in the stage of written language analysis, the researchers undertake the following stages: (1) Collecting all billboards that have been classified based on the parties winning the Indonesia general election in 2019 and the nationalist or Islamic strands; (2) Classifying based on 7 embodiments of clauses or words in persuasive discourse; (3) Analyzing slogans on billboards; (4) Drawing the conclusions. After the writer analyzes the visual and written language of the billboards, the writer combines them and as the result, the researchers can find the use of the language in the legislative candidates' billboards 
Table 1 Billboard From Golkar

\begin{tabular}{|c|c|}
\hline Slogans & $\begin{array}{c}\text { The Types of Persuasive } \\
\text { Discourse }\end{array}$ \\
\hline $\begin{array}{l}\text { Your struggle is become the half of mother's } \\
\text { prayer }\end{array}$ & wise clause \\
\hline sincerely work with heart & wise clause \\
\hline Choose no 3 & invitation \\
\hline Number of wise clauses & 2 \\
\hline Number of invitations & 1 \\
\hline The total of number & 3 \\
\hline
\end{tabular}

Table 2 Billboard From PKS

\begin{tabular}{ll}
\hline \multicolumn{1}{c}{ Slogans } & \multicolumn{1}{c}{ The Types of Persuasive Discourse } \\
\hline let's get better & invitation \\
\hline \#2019choosePKS & invitation \\
\hline $\begin{array}{l}\text { We can make 4 safe things for the people } \\
\text { such as worship, work, income and social }\end{array}$ & invitation \\
security & \\
\hline labors select labors & affirmation \\
\hline Number of Invitations & $\mathbf{3}$ \\
\hline Number of affirmations & $\mathbf{1}$ \\
\hline The total numbers & $\mathbf{4}$ \\
\hline
\end{tabular}

Based on the two tables above, we can see that on Billboard 1 from Golkar, there is a dominance of clauses or words of wisdom that conveys through the existing slogan. Using words / clauses wisely at the linguistic level indicates the purpose of the communicator to convey his thoughts to the viewers through the feelings that will continue towards thinking to determine attitudes. Words or clauses of wisdom also have characteristics, includes: having meaning or advice and the message can be immediately known only by reading once.

On billboard 1, the slogan " your struggle is the mother's prayer " is a wise speech that is correlated with the candidates through a picture of him and his mother. The slogan indicates that the mother's blessing prayer has a strong role in stepping through a struggle. While the slogans' sincerely work well ", the words' sincere 'and' good 'according to (Ekawati, 2015) when the writer has referred to the word assessment, in this context can lead to positive things. The last slogan that has found in billboard 1 is 'Chose no 3' which refers to the type of persuasive discourse that is an invitation and has become the most important element in an advertisement.

In contrast to billboards 2, the researchers found that the dominance of persuasive discourse in the slogan was an invitation. Sanz, (2016) explained that 
advertising in any form still prioritizes an invitation in order to make the people who see these advertisements can be influenced to do something desired by advertisers. Meanwhile the use of the hashtag \# 2019choosePKS, legislative candidates not only invite the public to choose PKS but their candidates also have a hidden meaning to support Prabowo-Sandiaga's stronghold which is widely supported on social media with the hashtag \# 2019changepresiden.

In the invitation 'Together, we are manifested 4 safe for the people' 'indicates that the legislative candidate promotes the quality side that will be manifested when he becomes a member of the legislative candidate.. Ali, (2019) explained that we need to improve the social intimacy to influence others, as the results they can do something that we suggest that they do voluntarily.

The dominance of the type of persuasive discourse on billboards number 2 shows that candidates has tried many ways to attract the sympathy and to support the viewers directly and openly. The assertion on the billboard " labors choose labors " directly shows the identity of candidates as workers who have the same experienced and fate as the other labors. It is proven that the legislative candidates expect that labors who see the billboards will be directly affected to choose him. Even though according to the official website KPU, the names of the two legislative candidates on the billboard have failed to advance as the legislative candidates in general election 2019 in Indonesia but the phenomenon of outdoor political advertising can be seen from the strands and political situation in Indonesia.

From the graphic above, we can know that the dominance of persuasive discourse of the two billboards is an invitation which implies that the billboards has contained the strong persuade to the people to choose them as the legislative candidates.

\section{DISCUSSION}

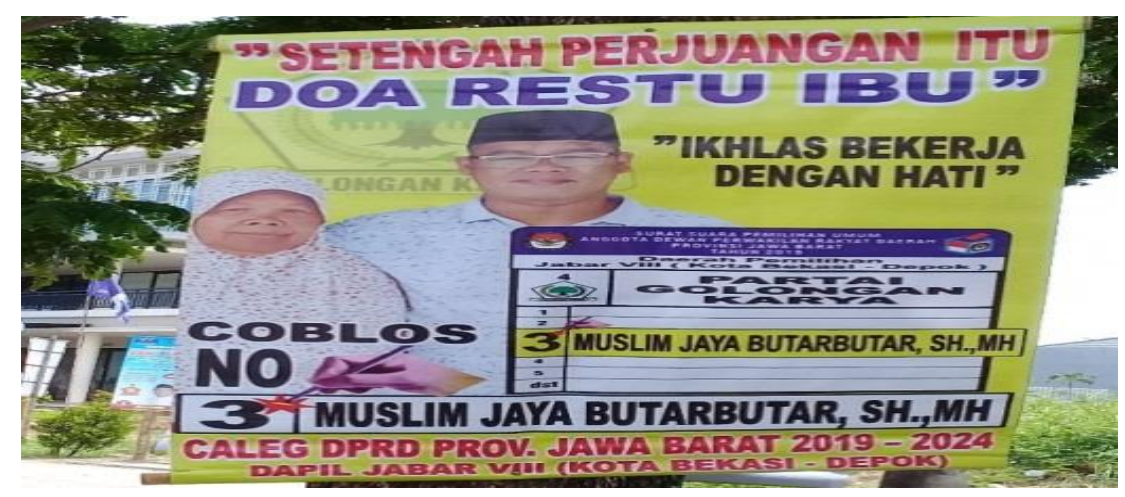

Picture 1 The legislative Candidate from the Golkar Party 
The billboard above is a portrait that has been taken by the researchers in Bekasi. It is a billboard from the legislative candidate from the Golkar party. Airlangga Hartanto stated that the Golkar party is a nasionalist party, as quoted from the official website of Golkar.

The researchers will begin to analyze the visual reading elements commonly used in social semiotic analysis that is from the right to the left. First, we will focus on the color of the background of the billboard. Yellow has become the official color of the Golkar party. Quoted from the official website of the Golkar party, yellow is interpreted as the prosperity which is inspired by yellow rice that are ready to be harvested. Indonesia is an agricultural country where the paddy fields are mostly planted with rice. The rice harvest season is also interpreted as the prosperity because it provides benefits for the farmers in terms of increased income and benefits for the country. It means that the country does not lack staple food which will be affected to the affordability of rice prices and reduce rice imports.

In the background of billboards, we also see the symbol of banyan tree, rice and cotton which are the official symbols of the Golkar party. According to the official Golkar website, the banyan tree is symbolized as a large tree which is a shade. The banyan tree in the Golkar party is interpreted that Golkar is a party that serves as a refuge for all Indonesian people. Rice and cotton are symbolized as social welfare for all Indonesian people. The pentagon shield is interpreted as Pancasila which incidentally is the party's ideology. The white color which is the dominant color in the Golkar symbol is interpreted as purity. And there are 17 cotton flowers, 8 hanging roots on the banyan tree and 45 grains of rice which are the symbol of Indonesia independence day on 17-8-45. The choice of yellow which is the dominant color on billboards shows that the billboards will attract the attention of commuter viewers.

According to Sirel et al., (2010) in visual language, colors play a considerable role in attracting the human subconscious to know something in their minds. Golkar, a political party that was founded on 20 October 1964, has been using yellow as the official color of the party. According to Tapsell, (2015) Golkar is a big party as evidenced by its successive victories since the election of the New Order even until 2019, Golkar still occupies the position of a large party. Generally, the public know that the identity of the Golkar party is closely attached to the yellow color.

At the top right side, we can see the slogan " your struggle is mother's prayer ". In the classification of types of clauses / words in persuasive discourse, these slogans are grouped in the category of clauses that show wisdom. Because on the billboard, Muslims seemed to affirm their self-representation as children who serve their parents by pocketing the blessings of their mothers to step forward 
as legislative candidates for the regional cities of Bekasi and Depok. We also see a photo of Muslim together with his mother position on his right. According to Leeuwen, (2018) in the compositional metafunction, the position of the photo on the right side is interpreted as 'new' which is a solution or an existing issue. While the left position indicates 'given' or figures that are already known by the public.

On these billboards, they can be seen that the position of the photo of the Muslim's mother is a companion figure of her children who will fight in the general election 2019. Regarding the persuasive discourse, Martynova \& Borisova, (2017) states that in attracting the sympathy of others it is necessary to present a respected figure or respected parent figure made as role models. Muslims at these billboards use this method to create a respectful representation through his mother. Whereas in the interpersonal metafunction, Muslims displayed a figure that creates interactions with commuters who see the billboards. Simultaneously, Muslim and his mother have developed a strong interaction through their eyes that directly looked at the commuters and at the billboard and it is able to create the emotional closeness visually. In the picture, both the Muslim and his mother are wearing the simple clothes. Even his mother appeared not to wear makeup, as the result, it can be presented as a simple impression.

The wearing of the hijab and cap in the photo seems to add the Islamic image that has attached to them regardless of the cap and hijab as a religious attribute for Muslims. The wearing of glasses on Muslims also supports the development of his self-image. Sulastri \& Ronidin, (2016) based on the perspective of psychology, people who wear glasses look $40 \%$ more intelligent, insightful and authoritative. Moreover, Muslims also use academic degrees that he has got on the billboard, i.e. SH (bachelor of Law) and MH (masters of law). Based on the photos between Muslims and their mothers, we can see the image that Muslims want to build his reputation as pious persons through a muslim cap, which is one of the attributes used by Muslim men to pray. The figure of his mother wearing a hijab is also able to present the impression of a religious family.

Based on the billboard analysis above, we can conclude that Muslims as legislative candidates in the general elections 2019 want to build their self-images as religious persons as well as sincere figures at work. The context of the word 'working' on a billboard also represents the sincerity of a Muslim if he is elected as a member of the DPRD of Bekasi and Depok. Through the slogan that has been deployed on the billboards, we also see a persuasive discourse that leads to wise words namely "half the struggle is mother's blessing prayer," clause "sincerely works with heart" which leads to the affirmation because Muslims want to show a good and positive image that exists in him and also the clause " choose no. 3 " which refers to the invitation to the public to choose him. Even though Golkar party is a nationalist party, Muslims seem to want to attract the attention of the 
people who are Muslim especially to attach the religious image that he wants to convey.

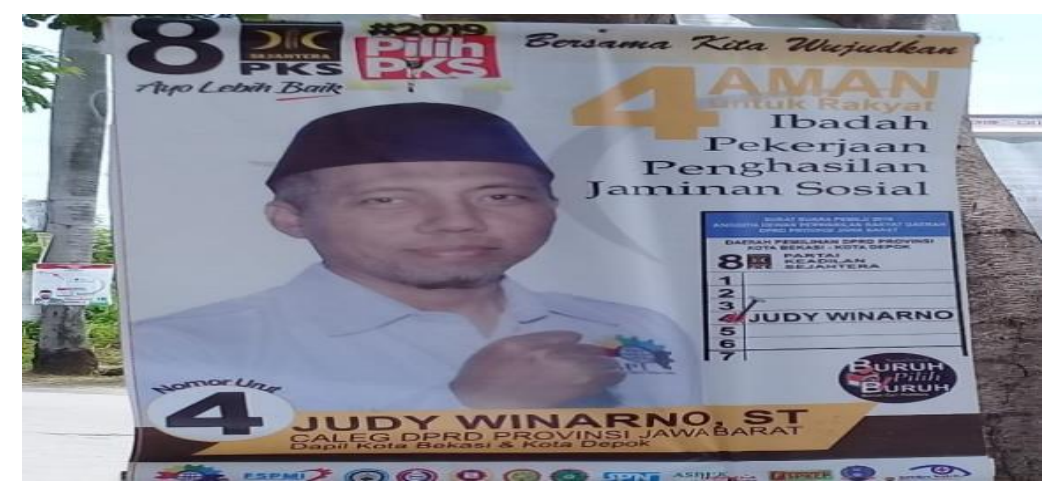

Picture 2 Billboard from PKS

The billboard above is a portrait that has been taken by the researchers in Bekasi. This billboard is from the candidates for the Prosperous Justice Party (PKS). Based on the PKS official website, it is proven that PKS claims as an Islamic party.

As the billboard analysis on the previous picture, the researchers will also begin the analysis from visual reading elements. According to (Leeuwen, 2018), analysis of social semiotic starting from right to left side. When we focus on the background color on the billboard, the dominant clolor is white. According to the official website of PKS, the white color in the symbol of PKS with the meaning of being clean and also symbolizes purity of heart. The shape of a rectangular box on the PKS symbol indicates three principles of PKS, such as: Equality, regularity and harmony. PKS also uses a crescent symbol that symbolizes the victory of Islam, beauty, happiness and enlightenment.

The dominance of the crescent symbol on the PKS indicates that PKS wants to emerge as an Islamic party like the Crescent Star Party (PBB) which also claims to be an Islamic party that uses the moon symbol on its party logo. The strand of upright rice implies four things, such as: justice, ukhuwah, istiqomah and welfare. The golden yellow symbolizes three things, such as: brilliance, excitement and glory. While the dominant black color in PKS symbolizes aspiration and certainty. There is the slogan " let's get better " which is the official slogan of PKS for the general election in 2019. it is classified into the type of persuasive discourse i.s. invitation, then the slogan is intended in the type of invitation clause.

Based on the PKS official website, the meaning of " let's get better " is a persuasive invitation to all groups both of workers and unemployed to move towards a better condition of Indonesia. Slogan " let's get better " actually is the essence of the call from kiai who are tasked for delivering a call about goodness 
and bringing people towards a better condition or in Islamic term known as amar ma'ruf nahi munkar.

Meanwhile, Hermawan, (2013) stated that the word 'better' is a series of words that has the meaning 'increasing' and it is different from the word 'best'. In a series of words 'better' is an activity that can be done by ourselves without being influenced by other objects and can be a motivator for others in being competitive to do something. But, in the word 'best' it is a comparison that must involve at least three objects. Based on these explanations, we know that the slogan " let's get better " is a positive invitation and can be done by anyone and individually.

At the top of the billboard, we also see the hashtag \# 2019choosePKS. It is included as persuasive discourse that is an invitation. Based on the great dictionary of Indonesian language 2019, the word 'choose' has two meanings, such as: (1) determine something based on his preferences; (2) appoint (people, candidates and so on) by voting. In this context the word 'select' is intended for commuters who view the billboard to choose PKS in the general election 2019. The hashtag \#2019 in the 2019 also refers to the supporters of Prabowo - Sandi (the candidate of president and vice president of Indonesia) who is widely used to campaign on social media with the hashtag \# 2019changepresident.

Based on the Indonesian Survey Institute (LSI) website, revealed that there was the hashtag war on social media, especially on twitter. The data that has been reported from LSI as of March 25, 2019 was based on the records from Twitter which noted that the hashtag \# 2019 which was a presidential support for Prabowo-Sandi has reached a range of 76,440 , which is actually less than the hashtag \# Jokowi2period, which has reached 157,718. Sopian, the head of PKS reported in the Media Indonesia website and explained that the hashtag \# 2019 choosePKS was a form of the support of PKS for Prabowo-Sandi as the 2019 presidential and vice presidential candidates.

At the top of the left side of the billboard, we can see the slogan " Together we make 4 safe for the people such as worship, work, income and social security ". These slogans are classified into the type of persuasive discourse that is an invitation. The word 'together' represents the declaration from Judy toward the people. In this case it can be seen that Judy wants to build emotional closeness with the people by embracing them in realizing the 4 things that he will carry out after he has been elected as a legislative candidate.

According to Khan et al., (2016) the vision and mission that was put forward in a campaign has a function to make the people see the goals and plans of each candidate clearly. When making decisions about the vision and mission, the candidates will make plans through adaptation with the social situations. As the result, they can draw conclusions about what needed by the people. On the billboard, Judy seemed to offer 4 visions and missions that have been summarized 
by the word 'safe'. Based on the great dictionary of Indonesian language 2019, The word 'safe' has three meanings, such as: (1) free from distractions; (2) surely, no doubt; (3) peaceful, not afraid or worried. Judy through the word 'safe' seems to convey the invitation to the people in social life that are arranged through 4 things, such as: worship, work, income and social security. On the billboards, Judy prioritizes the word 'worship' which correlates with religious discourse. The word 'worship' on a billboard is also able to show the religious side of a Judy.

In Judy's picture, we can see that he is wearing a cap which incidentally is one of the attributes in Islam, used by Muslim men when performing prayers. Judy is also wearing a white collar that seems to blend with the background color of the billboard and also the logo of the FSPMI (Federation of Indonesian Workers' Union) which is a trade union organization. He wears FSPMI emblem and he also shows his identity as the head of the FSPMI central leadership. According to Leeuwen, (2018) in a photograph, the person can make a narration through his gestures. On the billboard, Judy seemed to put his right hand up as he looked at the commuters who looked directly to the billboard.

Judy clenched his right hand which indicated a form of defense against the community while describing the 4 actions that he would take if he was elected as a member of the legislative candidate. As on general campaign billboards, on the billboards above there are examples of ballots that will be used in the next election accompanied by a party serial number and also the serial number of Judy. The picture also conveys the value of information to prospective voters regarding the procedures for selecting Judy in the election.

At the bottom left side, we can see the slogan 'labors select labors' which refers to the type of persuasive discourse of affirmation. In the slogan, the viewers seemed to be given information about the identity of Judy. Reporting from his Facebook social media, Judy said that he was a laborer who had worked in Bekasi area for many years. The layout of billboards he placed in Bekasi is known as an industrial area, because there are several factories that stand and operate in the area. From this slogan, we can also see that Judy wants to capture the majority of the workers who lived in Bekasi area. At the bottom of the billboard, we can see the various symbols from various trade unions and labor organizations. It is proved that Judy was supported by a majority of the trade unions and workers.

Based on the analysis of billboards from the PKS party, we can see that PKS, which is an Islamic party strands, also highlights the Islam side on the billboards. Judy as a legislative candidate from PKS is strong enough to highlight the Islam side of the billboard both from the cap that he is used and from the word 'worship' which was the first written as a mission from herself to the people. The use of white as the background of the billboard and the dominant color has proven 
to show a " holiness " which has attached to the billboard regardless of the image of PKS and Judy.

\section{CONCLUSION}

Based on the analysis of two campaign billboards from two different legislative candidates, the researchers have found that many billboards are scattered along the road during the campaign of general elections 2019 in Indonesia and they used them as the source to make a research. The approach of Social semiotics can increase our understanding in an image or photograph. Similarly, persuasive discourse that enables us to see a slogan / tagline from the perspective of language. The visual language that has displayed on the billboard also features a narrative that is able to uncover hidden meanings in campaign advertising. Candidates who compete in the seat of government will always put their identity and convey an implicit and explicit message.

\section{REFERENCES}

Adhani, A., Putranto, A., Wijiharto, P., Nurjanah,. (n.d.). Dinamika Media dan Budaya. Sosio-Didaktika: Social Science Journal, 1(1), 111-121.

Ali, M. (2019). Influence of the Sub Conscious Mind in Consumer Psychology of Buying in Contemporary ERA. Shanlax International Journal of Commerce, 7(3), 1-10. https://doi.org/10.34293/commerce.v7i3.521

Bahri, S. (2018). A Semiotic on the Headlines of Political Party's Advertisements in Jakarta Post. PIONEER: Journal of Language and Literature, 10(1), 6173.

Ekawati, R. (2015). Language Appraisal on Attitudinal Systems for Exploring Ideology in Death Penalty in Sydney Morning Herald and Herald Sun editorials. Jurnal Humaniora, 27(3), 362-372.

Everbach, T., Batsell, J., Champlin, S., \& Nisbett, G., S. (2019). Does a More Diverse Newspaper Staff Reflect Its Community? A Print and Digital Content Analysis of The Dallas Morning News. Southwestern Mass Communication Journal, 34(1), 82-92.

Glavas, D. (2017). Political Advertising and Media Campaign During the Preelection Period: A Comparative Study Commissioned by the OSCE Mission to Montenegro Author: Davor Glavaš. Journal of Advertising, 31(1), 13-25.

Hermawan, B. (2013). Multimodality: Menafsir Verbal, Membaca Gambar, dan Memahami Teks. Jurnal Pendidikan Bahasa dan Sastra, 13(1), 19-28.

Khan, K., Karamatullah H., S., Khan, A., \& Khan, H. (2016). Billboard Advertising and Customer Attention: A Pakistani Perspective. International Journal of Scientific and Research Publications, 6(3), 502513.

Leeuwen, T. (2018). Moral Evaluation in Critical Discourse Analysis. Critical Discourse Studies, Journal of cleaner production, 15(2), 140-153. https://doi.org/10.1080/17405904.2018.1427120

Martynova, A., \& Borisova, O. (2017). Comparing the Effectiveness of Outdoor Advertising with Internet Advertising: Case Study: Inetcom Company, 
Journal of Humanities and Social Sciences, 8(19), 12-21. https://doi.org/10.1177/1468794111401697

Richardson, J., E. (2007). Analysing Newspapers-An Approach form Critical Discourse Analysis, Journal of Human Subjectivity, 9(2), 67-93.

Rizki, I., Usman, B., Samad, I.,A., Muslim, A., \& Mahmud, M. (2019). Rhetorical Pattern of Political Advertisement in Aceh. Studies in English Language and Education, 6(2), 212-227. https://doi.org/10.24815/siele.v6i2.13851

Sirel, K., Aas, T., V., Mcguinness, J., Maria, R., \& Kraze, S. (2010). The Language of Advertising: Powerful, Innovative and Environmental? New Perspectives on Sustainability, Journal of Creative Communications, 12(3), 239-249.

Spenkuch, Jj. L., \& Toniatti, D. (2015). Political Advertising and Election Outcomes. International Studies Review, 18(1), 33-47. https://doi.org/10.2139/ssrn.2613987

Sulastri, S., \& Ronidin, R. (2016). Fenomena Bahasa Baliho Sebagai Identitas Diri Tokoh Cerminan Karakter Budaya: Kajian Semiotika. Jurnal Sosioteknologi,13(1),48-59. https://doi.org/10.5614/sostek.itbj.2014.13.1.6

Sans, J., P., M. (2016). Relevance Theory and Political Advertising. A Case Study. European Journal of Humour Research, 1(2), 10-23. https://doi.org/10.7592/ejhr2013.1.2.jesuspinarsanz

Tapsell, R. (2015). Indonesia's Media Oligarchy and the "Jokowi Phenomenon." Indonesia, Critical Asian Studies, 49(3), 411-427.

Udalla, E. (2016). Party Politics and Electioneering Campaign Of PDP / APC In The Nigeria' S 2015 Presidential Election. African Journal of Politics \& Society, 2(2), 30-60. 